\title{
Antibacterial activity of endophytic fungi from leaves of Indigofera suffruticosa Miller (Fabaceae)
}

\author{
Irailton Prazeres dos Santos ${ }^{1,2}$, Luís Cláudio Nascimento da Silva ${ }^{2}$, \\ Márcia Vanusa da Silva ${ }^{2 *}$, Janete Magali de Araújo $^{3}$, Marilene da Silva Cavalcanti ${ }^{1}$ and \\ Vera Lucia de Menezes Lima ${ }^{2 *}$ \\ 1 Departamento de Micologia, Centro de Ciências Biológicas, Universidade Federal de Pernambuco, Recife, Brazil, \\ ${ }^{2}$ Departamento de Bioquímica, Centro de Ciências Biológicas, Universidade Federal de Pernambuco, Recife, Brazil, \\ ${ }^{3}$ Departamento de Antibióticos, Centro de Ciências Biológicas, Universidade Federal de Pernambuco, Recife, Brazil
}

\section{OPEN ACCESS}

Edited by:

Helen Zgurskaya,

University of Oklahoma, USA

Reviewed by:

Yuji Morita,

Aichi Gakuin University, Japan

Dinesh Sriramulu,

Shres Consultancy, India

${ }^{*}$ Correspondence:

Márcia Vanusa da Silva and

Vera Lucia de Menezes Lima,

Departamento de Bioquímica, Centro

de Ciências Biológicas,

Universidade Federal

de Pernambuco, Avenida Professor

Moraes Rêgo, S/N, Cidade

Universitária, Recife, Pernambuco,

Brazil

marcia.vanusa@ufpe.br;

lima.vera.ufpe@gmail.com

Specialty section

This article was submitted to Antimicrobials, Resistance

and Chemotherapy,

a section of the journal

Frontiers in Microbiology

Received: 22 January 2015 Accepted: 08 April 2015

Published: 07 May 2015

Citation:

Santos IP, Silva LCN, Silva MV,

Araújo JM, Cavalcanti MS and

Lima VLM (2015) Antibacterial activity

of endophytic fungi from leaves

of Indigofera suffruticosa Miller

(Fabaceae)

Front. Microbiol. 6:350.

doi: 10.3389/fmicb.2015.00350
Endophytic fungi were isolated from healthy leaves of Indigofera suffruticosa Miller, a medicinal plant found in Brazil which is used in folk medicine to treat various diseases. Among 65 endophytic fungi isolated, 18 fungi showed activity against at least one tested microorganism in preliminary screening, and the best results were obtained with Nigrospora sphaerica (URM-6060) and Pestalotiopsis maculans (URM6061). After fermentation in liquid media and in semisolid media, only N. sphaerica demonstrated antibacterial activity (in Potato Dextrose Broth-PDB and in semisolid rice culture medium). In the next step, a methanolic extract from rice culture medium (NsME) and an ethyl acetate extract (NsEAE) from the supernatant of PDB were prepared and both exhibited antimicrobial activity against Gram-negative and Gram-positive bacteria. The best result was observed against Staphylococcus aureus, with minimum inhibitory concentration $(\mathrm{MIC})$ and minimum bactericidal concentration $(\mathrm{MBC})$ values of 1.56 $\mathrm{mg} / \mathrm{mL}$ and $6.25 \mathrm{mg} / \mathrm{mL}$, respectively, for NsME and MIC and MBC values of 0.39 $\mathrm{mg} / \mathrm{mL}$ and $3.12 \mathrm{mg} / \mathrm{mL}$, respectively, for NsEAE. This study is the first report about the antimicrobial activity of endophytic fungi residing in I. suffruticosa leaves, in which the fungus $N$. sphaerica demonstrated the ability to produce bioactive agents with pharmaceutical potential, and may provide a new lead in the pursuit of new biological sources of drug candidates.

Keywords: antibacterial activity, endophytic microorganisms, minimum inhibitory concentration, Nigrospora sphaerica, Staphylococcus aureus

\section{Introduction}

The development of resistance by existing pathogenic bacteria and fungi to commercial drugs is a relevant problem faced by health services (Costelloe et al., 2010) and has become a serious concern around the world (Aksoy and Unal, 2008). Several factors have favored this scenario, such as extensive and often inappropriate use of antibiotics, poor hygienic conditions, continuous movement of travelers, increased numbers of immunocompromised patients, and delay in diagnosis of infections (von Nussbaum et al., 2006). As a result, an intensive search for new, effective antimicrobial agents is necessary, which is facilitated by exploring new niches and habitats (Xing et al., 2011; Zhao et al., 2011a). 
A range of microbial species are known to be endophytic, colonizing inter- and intracellular spaces of plant tissues without causing apparent damage and appearing to be associated with all plants in natural ecosystems (Rodriguez et al., 2009). Among endophytic microorganisms, fungi have an intimate relationship with host plants and can produce compounds that promote vegetative growth, competitiveness and protection of the host against herbivores and pathogens (Porras-Alfaro and Bayman, 2011). Endophytic fungi represent a wide diversity of microbial adaptations that have evolved in special and unusual environments, making them a great source of study and research for new drugs for medical, industrial, and agriculture uses (Yu et al., 2010; Li et al., 2012; Teiten et al., 2013; Mapperson et al., 2014). These microorganisms are well known to produce bioactive secondary metabolites such as alkaloids, terpenoids, steroids, quinones, isocoumarins, lignans, phenylpropanoids, phenols, and lactones (Radić and Štrukelj, 2012; Deshmukh et al., 2014).

Plants used in traditional medicine have played a very important role in the search for new bioactive strains of endophytic fungi, as it is possible that their beneficial characteristics are a result of the metabolites produced by their endophytic community (Kaul et al., 2012; Kusari et al., 2013). Despite this potential, a repertoire of medicinal plants remains to be studied regarding their endophytic composition, for example Indigofera suffruticosa Miller. This is a well-known Brazilian medicinal plant whose leaves have been proven to have anti-inflammatory, anticonvulsant antimicrobial, and wound-healing properties (Leite et al., 2004, 2006; Carli et al., 2010; Luiz-Ferreira et al., 2011; Almeida et al., 2013; Chen et al., 2013; Bezerra dos Santos et al., 2015). Due to the medicinal properties of I. suffruticosa, this species was the focus in the present study of a search for endophytic fungi able to produce bioactive substances with antimicrobial activity.

\section{Materials and Methods}

\section{Plant Samples}

The collection of plant samples was performed in Igarassu $\left(07^{\circ} 50^{\prime} 00^{\prime \prime} \mathrm{S} 34^{\circ} 54^{\prime} 30^{\prime \prime} \mathrm{W}\right)$, Atlantic Coastal Forest, Pernambuco, Brazil. Samples were immediately processed in the Mycology Department, Federal University of Pernambuco (UFPE), Recife, Brazil.

\section{Isolation of Endophytic Fungi}

In order to eliminate epiphytic microorganisms, plant samples were superficially sterilized by the method described by Araújo et al. (2002). Healthy leaves of I. suffruticosa were washed in running tap water, followed by immersion in $70 \%$ ethanol for $1 \mathrm{~min}$, in sodium hypochlorite $(2.0-2.5 \%$ available chlorine) for $4 \mathrm{~min}$, in $70 \%$ ethanol for $30 \mathrm{~s}$ and washed three times with sterilized, distilled water. The efficiency of sterilization was confirmed by inoculating water from the last washing into Petri dishes containing potato dextrose agar (PDA; containing potato $(200 \mathrm{~g} / \mathrm{L})$, dextrose $(20 \mathrm{~g} / \mathrm{L})$, and agar (15 g/L), pH 6.0). After surface sterilization, the samples were cut into $0.5 \mathrm{~cm}^{2}$ pieces and aseptically transferred to Petri dishes containing PDA culture medium supplemented with chloramphenicol $(100 \mu \mathrm{g} / \mathrm{mL})$ to suppress bacterial growth. The Petri dishes were incubated at $30^{\circ} \mathrm{C}$ for 30 days and checked daily, and all fungal colonies found were isolated, purified and maintained in PDA for later testing.

\section{Screening of Antimicrobial Acitivity Tested Microorganisms}

Among the microorganisms used for antimicrobial tests, five were fungi pathogenic to humans (Candida albicans, URM-5852; Epidermophyton flocosum, URM-5510; Malassezia furfur, URM-5389; Microsporum gypsseum, URM5478; and Trichophyton mentagrophytes, URM-5589) URM Culture Collection (WDCM604) of the Federal University of Pernambuco, Recife, Brazil. The other five microorganisms were bacteria obtained from the Culture Collection UFPEDA, Department of Antibiotics, UFPE, Recife, Brazil, two of which were Gram-positive bacteria (Staphylococcus aureus, UFPEDA-02; and Bacillus subtilis, UFPEDA-16), and three were Gram-negative (Escherichia coli, UFPEDA-224; Klebsiella pneumoniae, UFPEDA-396; and Pseudomonas aeruginosa, UFPEDA-39).

\section{Antimicrobial Assay}

The endophytic fungi were subjected to an antimicrobial assay using a solid medium (Ichikawa et al., 1971) which permits a rapid and qualitative selection of the bioactive microorganisms. Each endophytic strain was cultivated on the surface of PDA in Petri dishes, at $30^{\circ} \mathrm{C}$, for 7 days. Then, disks were cut from the PDA plate (6 $\mathrm{mm}$ diameter) and transferred to the surface of Petri dishes previously spread with bacteria (Müller-Hinton agar, MHA) and fungi [Sabouraud dextrose agar (SDA) and SDA supplemented with $0.5 \%$ olive oil for $M$. furfur]. The Petri dishes were incubated at $37^{\circ} \mathrm{C}$ during $24 \mathrm{~h}$ for bacterial growth, and at $30^{\circ} \mathrm{C}$ during $48 \mathrm{~h}$ for fungal growth. Antimicrobial activity was assayed by the measurement of any inhibition diameter zones (IDZ).

\section{Identification of Endophytic Fungi}

The identification of endophytic fungi was performed at the Mycology Department, UFPE, Recife, Pernambuco, Brazil, by means of analysis of macroscopic and microscopic characteristics of colonies. After identification, fungi that showed antimicrobial activity were stored in the URM Culture Collection (WDCM604) of the Federal University of Pernambuco, Recife, Brazil.

\section{Fermentation Assay in Liquid Medium}

Strains that showed the best results in the antimicrobial screening were further examined using a diffusion assay, in order to provide a way to select the best medium and incubation time for the production of the bioactive metabolites. Pre-inoculum were prepared in $250 \mathrm{~mL}$ Erlenmeyer flasks by adding five plugs (6 mm of diameter) of growing culture and $50 \mathrm{~mL}$ of PDB (potato: $200 \mathrm{~g} / \mathrm{L}$; dextrose: $20 \mathrm{~g} / \mathrm{L} ; \mathrm{pH}$ 6.0). All cultures were incubated at $28 \pm 2{ }^{\circ} \mathrm{C}$, on a rotary shaker, at $180 \mathrm{rpm}$. An aliquot $(10 \mathrm{~mL})$ of each pre-inoculum was transferred to $500 \mathrm{~mL}$ Erlenmeyer flasks containing $90 \mathrm{~mL}$ of the following media: PDB, Sabouraud broth (SAB), Malt Extract 
Broth (MEB; malt extract: $20 \mathrm{~g} / \mathrm{L}$ ), or Eurimycin Production Medium (EPM; soy flour: $20 \mathrm{~g} / \mathrm{L}$; glucose: $20 \mathrm{~g} / \mathrm{L} ; \mathrm{CaCO}_{3}$ : $2 \mathrm{~g} / \mathrm{L}$; and $\mathrm{NaCl}: 5 \mathrm{~g} / \mathrm{L}$ ). The flasks were incubated under the same conditions $\left(28 \pm 2{ }^{\circ} \mathrm{C}\right.$, on a rotary shaker, at $180 \mathrm{rpm}$ for $96 \mathrm{~h}$ ). Every $24 \mathrm{~h}$, samples of $1 \mathrm{~mL}$ from the fermentation broth were centrifuged for $15 \mathrm{~min}$ (Siqueira et al., 2011). For the fermentation in the liquid medium $\mathrm{PDB}$, the endophytic fungi were grown on $\mathrm{PDA}$, at $25^{\circ} \mathrm{C}$, for 5 days. Three pieces $(0.5 \mathrm{~cm} \times 0.5 \mathrm{~cm})$ of mycelial agar plugs were inoculated into $500 \mathrm{~mL}$ Erlenmeyer flasks containing $300 \mathrm{~mL}$ of potato dextrose broth and incubated at room temperature for 4 weeks. The cultures were filtered and the wet mycelia were discarded (Trisuwan et al., 2008). For the antimicrobial activity test, $30 \mu \mathrm{L}$ of each supernatant obtained was utilized according to the disk diffusion method proposed by Bauer et al. (1966).

\section{Fermentation Assay in Semisolid Medium}

The endophytes that showed the largest IDZ against the largest number of test microorganisms were cultured in the center of Petri dishes containing the medium PDA at $28 \pm 2^{\circ} \mathrm{C}$ for 7 days, and from these colonies, five blocks of $5 \mathrm{~mm}$ diameter were transferred to Erlenmeyer flasks $(1000 \mathrm{~mL})$ containing the rice or corn semisolid media.

The preparation of semi-solid media was performed according to the methodology described by Aly et al. (2008), where $100 \mathrm{~g}$ of commercially available rice or corn and $100 \mathrm{~mL}$ of distilled water were added to Erlenmeyer flasks, autoclaved three times on alternate days and cultivated with the fungi $N$. sphaerica and $P$. maculans in static conditions at room temperature for 30 days. After the incubation period, methanol $(300 \mathrm{~mL})$ was added to each Erlenmeyer flask, followed by maceration. After $24 \mathrm{~h}$, each sample was subjected to gravity filtration. The filtrate was concentrated on a rotary evaporator under reduced pressure at $50^{\circ} \mathrm{C}$ to obtain the methanolic extracts (NsME). The extract was kept at $-20^{\circ} \mathrm{C}$, and dissolved in dimethyl sulfoxide (DMSO) when ready for use.

\section{Preparation of Ethyl Acetate Extract From Fermentation Assay in Liquid Medium (PDB)}

The method described by Trisuwan et al. (2008) was used, where after the fourth week, the culture fermented by N. sphaerica was filtered in vacuum filter using a no. 3 Buchner funnel. The culture filtrates were extracted with ethyl acetate $(2 \times 300 \mathrm{~mL})$ by partitioning in a separating funnel (solvent-solvent extraction). The culture filtrates (ethyl acetate extract -NsEAE) was concentrated on a rotary evaporator under reduced pressure at $50^{\circ} \mathrm{C}$. The extract was kept at $-20^{\circ} \mathrm{C}$, and dissolved in dimethyl sulfoxide (DMSO) when ready for use.

\section{Phytochemical Analysis}

Phytochemical analytical tests were performed to detect the presence of steroids, saponins, alkaloids, flavonoids, tannins, reducing compounds, terpenoids, cinnamic derivatives, and anthracene derivatives, according to the method described by Kokate (1994) and Harborne (1998).

\section{Determination of Minimum Inhibitory and Minimum Bactericidal Concentrations}

A broth microdilution susceptibility assay was used for the determination of minimum inhibitory concentration (MIC) and minimum bactericidal concentration (MBC), as recommended by the National Committee for Clinical Laboratory (National Committee for Clinical Laboratory Standards [NCCLS], 2009). All tests were performed in Muller-Hinton broth. Bacteria were cultured overnight at $37^{\circ} \mathrm{C}$. The test samples of the extracts were dissolved in $10 \%$ DMSO. Dilutions were prepared in 96-well microtiter plates to get final concentrations ranging from 0 to $50 \mathrm{mg} / \mathrm{mL}$. After this step, each well received $10 \mu \mathrm{L}$ of the suspension of microorganisms and $100 \mu \mathrm{L}$ of liquid culture media. Plates were incubated at $37^{\circ} \mathrm{C}$ for $24 \mathrm{~h} ; 15 \mu \mathrm{L}$ of $0.01 \%$ resazurin was added as a colorimetric indicator of oxide reduction to characterize cell viability. Then the microplates were re-incubated for $4 \mathrm{~h}$, and the lowest concentration of the extract that inhibited microbial growth was recorded as the MIC. Using the results of the MIC assay, the concentrations showing a complete absence of visual growth of bacteria were identified, and $50 \mu \mathrm{L}$ of each culture broth were transferred onto the agar plates and incubated for the specified time and temperature as mentioned above. The complete absence of growth on the agar surface at the lowest sample concentration was defined as the MBC. Each assay in this experiment was replicated three times.

\section{Statistical Analysis}

Data were analyzed using GraphPad Prism by one-way analysis of variance (ANOVA) and Tukey to determine statistical significance. A $p$-value of $<0.05$ was considered to be statistically significant. The correlation index was calculated using the Pearson coefficient $(\rho)$.

\section{Results}

\section{Antimicrobial Activity Screening of Endophytic Fungi From Leaves of I. suffruticosa}

A total of 65 endophytic strains were isolated from leaves of $I$. suffruticosa and subsequently submitted to a preliminary antimicrobial screening on solid medium. A total of 18 endophytic isolates showed activity against at least two of the tested bacteria, thus $33.6 \%$ of the isolates were found to be active and the majority of these endophytic strains (except for N. sphaerica ISEF 13) also showed a wide spectrum, inhibiting both Gram-positive, and Gram-negative organisms (Table 1). On the other hand, none of the endophytic isolates showed any ability to inhibit the growth of any of the five fungi tested in this study. From those 18 active strains, all of them inhibited B. subtilis, while E. coli was not inhibited by only one of the four isolated strains of N. sphaerica, $S$. aureus, and K. pneumoniae were inhibited by $77.78 \%(14 / 18)$ and $72.22 \%(13 / 18)$ of the active endophytic strains, respectively. On the other hand, $P$. aeruginosa was only inhibited by one strain of N. sphaerica.

The strains N. sphaerica (URM-6060) and Pestalotiopsis maculans (URM-6061) showed the best action, and no significant 
TABLE 1 | Antibacterial activity of endophytic fungi isolated from leaves of Indigofera suffruticosa.

\begin{tabular}{|c|c|c|c|c|c|c|}
\hline & \multirow[t]{2}{*}{ Endophytic fungi } & \multicolumn{5}{|c|}{ Inhibition diameter zone (mm) } \\
\hline & & $\begin{array}{l}\text { Staphylococcus } \\
\text { aureus }\end{array}$ & $\begin{array}{l}\text { Bacillus } \\
\text { subtilis }\end{array}$ & $\begin{array}{l}\text { Escherichia } \\
\text { coli }\end{array}$ & $\begin{array}{l}\text { Klebsiella } \\
\text { pneumoniae }\end{array}$ & $\begin{array}{l}\text { Pseudomonas } \\
\text { aeruginosa }\end{array}$ \\
\hline ISEF 1 & Colletotrichum gloeosporioides & $26 \pm 2^{a}$ & $15 \pm 0^{\mathrm{a}}$ & $22 \pm 1^{a}$ & $22 \pm 2^{\mathrm{a}}$ & $0 \pm 0^{\mathrm{a}}$ \\
\hline ISEF 2 & C. gloeosporioides & $16 \pm 1.73^{b}$ & $24 \pm 1^{b}$ & $15 \pm 1.73^{b}$ & $28 \pm 2^{b}$ & $0 \pm 0^{\mathrm{a}}$ \\
\hline ISEF 3 & C. gloeosporioides & $26 \pm 1^{a}$ & $13 \pm 1.73^{\mathrm{c}}$ & $10 \pm 1^{c}$ & $26 \pm 0^{b}$ & $0 \pm 0^{a}$ \\
\hline ISEF 4 & C. gloeosporioides & $22 \pm 2^{c}$ & $12 \pm 0^{c}$ & $10 \pm 0^{c}$ & $26 \pm 1^{b}$ & $0 \pm 0^{a}$ \\
\hline ISEF 5 & Colletotrichum dematium & $0 \pm 0^{d}$ & $20 \pm 1^{d}$ & $11 \pm 1.73^{\mathrm{c}}$ & $24 \pm 1^{\mathrm{a}}$ & $0 \pm 0^{a}$ \\
\hline ISEF 6 & Curvularia pallescens & $0 \pm 0^{d}$ & $11 \pm 0^{c}$ & $10 \pm 0^{c}$ & $0 \pm 0^{c}$ & $0 \pm 0^{a}$ \\
\hline ISEF 7 & C. pallescens & $0 \pm 0^{d}$ & $12 \pm 1^{c}$ & $12 \pm 0^{c}$ & $0 \pm 0^{c}$ & $0 \pm 0^{a}$ \\
\hline ISEF 8 & Lasiodiplodia theobromae & $14 \pm 0^{\mathrm{e}}$ & $15 \pm 1.73^{\mathrm{a}, \mathrm{c}}$ & $21 \pm 1.73^{a}$ & $23 \pm 1.73^{a}$ & $0 \pm 0^{\mathrm{a}}$ \\
\hline ISEF 9 & L. theobromae & $32 \pm 2^{f}$ & $13 \pm 1.73^{\mathrm{c}}$ & $20 \pm 1^{a}$ & $12 \pm 1^{d}$ & $0 \pm 0^{a}$ \\
\hline ISEF 10 & Mycelia sterilia & $22 \pm 1^{c}$ & $22 \pm 1^{b, d}$ & $14 \pm 2.64^{b}$ & $26 \pm 1^{b}$ & $0 \pm 0^{a}$ \\
\hline ISEF 11 & M. sterilia & $18 \pm 1^{b}$ & $32 \pm 1.73^{e}$ & $13 \pm 1^{b}$ & $21 \pm 1.73^{a}$ & $0 \pm 0^{a}$ \\
\hline ISEF 12 & M. sterilia & $14 \pm 1.73^{\mathrm{b}, \mathrm{e}}$ & $15 \pm 1.73^{a}$ & $10 \pm 0^{c}$ & $15 \pm 1$ & $0 \pm 0^{a}$ \\
\hline ISEF 13 & Nigrospora sphaerica & $16 \pm 1.73^{b}$ & $14 \pm 0^{c}$ & $0 \pm 0^{d}$ & $0 \pm 0^{c}$ & $0 \pm 0^{a}$ \\
\hline ISEF 14 & N. sphaerica & $12 \pm 1^{e}$ & $12 \pm 1^{\mathrm{c}}$ & $14 \pm 1^{\mathrm{b}}$ & $0 \pm 0^{c}$ & $0 \pm 0^{\mathrm{a}}$ \\
\hline ISEF 15 & N. sphaerica & $13 \pm 1.73^{e}$ & $16 \pm 0^{a}$ & $14 \pm 0^{b}$ & $12 \pm 0^{d}$ & $0 \pm 0^{a}$ \\
\hline ISEF 16 & N. sphaerica (URM-6060) & $36 \pm 1^{f}$ & $28 \pm 2^{f}$ & $34 \pm 1.73^{\mathrm{e}}$ & $28 \pm 1^{b}$ & $12 \pm 1.73^{\mathrm{b}}$ \\
\hline ISEF 17 & Pestalotiopsis maculans (URM-6061) & $34 \pm 1^{f}$ & $28 \pm 1^{f}$ & $26 \pm 1^{f}$ & $27 \pm 1^{b}$ & $0 \pm 0^{a}$ \\
\hline ISEF 18 & Phomopsis archeri & $0 \pm 0^{d}$ & $14 \pm 1.15^{\mathrm{a}, \mathrm{c}}$ & $14 \pm 1^{b}$ & $0 \pm 0^{c}$ & $0 \pm 0^{\mathrm{a}}$ \\
\hline
\end{tabular}

The same superscript letter ${ }^{(a-f)}$ indicates no significant difference $(p>0.05)$ between inhibition diameter zones (IDZ) values from different endophytic fungi against each pathogen (same column).

TABLE 2 | Antimicrobial activity N. sphaerica (URM-6060) isolated from leaves of $I$. suffruticosa cultivated in different growth media.

\begin{tabular}{llllll}
\hline Culture & \multicolumn{5}{c}{ Inhibition diameter zone (mm) } \\
\cline { 2 - 6 } & S. aureus & B. subtilis & $\boldsymbol{E}$. coli & $\boldsymbol{K}$. pneumoniae & $\boldsymbol{P}$. aeruginosa \\
\hline SAB & $0 \pm 0^{\mathrm{a}}$ & $0 \pm 0^{\mathrm{a}}$ & $20 \pm 1^{\mathrm{a}}$ & $0 \pm 0^{\mathrm{a}}$ & $0 \pm 0^{\mathrm{a}}$ \\
MEB & $0 \pm 0^{\mathrm{a}}$ & $0 \pm 0^{\mathrm{a}}$ & $0 \pm 0^{\mathrm{b}}$ & $0 \pm 0^{\mathrm{a}}$ & $0 \pm 0^{\mathrm{a}}$ \\
EPM & $0 \pm 0^{\mathrm{a}}$ & $0 \pm 0^{\mathrm{a}}$ & $0 \pm 0^{\mathrm{b}}$ & $0 \pm 0^{\mathrm{a}}$ & $0 \pm 0^{\mathrm{a}}$ \\
PDB & $30 \pm 1^{\mathrm{b}}$ & $36 \pm 1^{\mathrm{b}}$ & $32 \pm 2^{\mathrm{c}}$ & $26 \pm 1^{\mathrm{b}}$ & $28 \pm 1^{\mathrm{b}}$ \\
Rice & $15 \pm 1.73^{\mathrm{c}}$ & $18 \pm 2^{\mathrm{c}}$ & $16 \pm 1^{\mathrm{d}}$ & $11 \pm 1.73^{\mathrm{c}}$ & $12 \pm 1^{\mathrm{c}}$ \\
Corn & $0 \pm 0^{\mathrm{a}}$ & $0 \pm 0^{\mathrm{a}}$ & $0 \pm 0^{\mathrm{b}}$ & $0 \pm 0^{\mathrm{a}}$ & $0 \pm 0^{\mathrm{a}}$ \\
\hline
\end{tabular}

The same superscript letter ${ }^{(a-d)}$ indicates no significant difference $(p>0.05)$ between IDZ values from strain URM-6060 cultivated in different growth media against each pathogen (same column).

differences $(p>0.05)$ were observed between their IDZ against most of the tested pathogens (except to E. coli and P. aeruginosa, which were more efficiently inhibited by the strain URM-6060) These two strains were stored in the URM Culture Collection (WDCM604) and submitted to the other assays.

\section{Fermentation Assays in Liquid and Semisolid Medium}

The antimicrobial activity of the two most active strains ( $N$. sphaerica URM-6060 and P. maculans URM-6061) was evaluated by liquid and semisolid fermentation assays using different growth media. N. sphaerica URM-6060 showed antimicrobial activity against all tested bacteria, but only when it was grown in rice and PDB media. The best activity was observed in PDB medium against all pathogens $(p<0.05)$ with inhibition zones of $36,32,30,28$, and $26 \mathrm{~mm}$ against $B$. subtilis, $S$. aureus, E. coli, $P$. aeruginosa, and $K$. pneumoniae, respectively, (Table 2). When cultivated in SAB, the strain URM-6060 only inhibited the growth of E. coli $(20 \mathrm{~mm})$. In semi-solid media, only the methanol extract obtained from rice medium (NsME) showed antimicrobial activity with IDZ ranging from 18 (B. subtilis) to $11 \mathrm{~mm}$ (K. pneumoniae). Interestingly, a strong correlation could be observed between the IDZ values obtained with PDB and rice media $(\rho=0.97)$. On the other hand, the strain P. maculans URM-6061 was not able to produce extracellular antimicrobial compounds in any of the tested media.

\section{Minimum Inhibitory and Minimum Bactericidal Concentrations of the NsME and NsEAE Extracts of the Endophytic Fungus $N$. sphaerica (URM-6060)}

The NsME (methanolic extract obtained from rice culture medium) and NsEAE (ethyl acetate extract obtained from the filtrate of PDB medium) were subjected to the microdilution test to determine the MIC and MBC, as shown in Table 3. NsME was more active against $S$. aureus, B. subtilis, and $P$. aeruginosa (MIC of $1.56 \mathrm{mg} / \mathrm{mL}$ for all), followed by $E$. coli and K. pneumoniae (MIC of $6.25 \mathrm{mg} / \mathrm{mL}$ ). Furthermore, the MBC values of NsME ranged from 6.25 to $50 \mathrm{mg} / \mathrm{mL}$, and it predominantly showed bacteriostatic actions (MBC/MIC $\geq 4$; Pankey and Sabath, 2004; except for K. pneumoniae; MBC/MIC ratio of 2).

The best antimicrobial action was found with NsEAE as its MIC values ranged from 0.39 to $3.12 \mathrm{mg} / \mathrm{mL}$ and $\mathrm{MBC}$ values 
TABLE 3 | Minimum Inhibitory and Minimum Bactericidal Concentrations of extracts of N. sphaerica (URM-6060) isolated from leaves of I. suffruticosa against human pathogens.

\begin{tabular}{|c|c|c|c|c|c|c|c|c|c|c|}
\hline \multirow[t]{3}{*}{ Extract } & \multicolumn{10}{|c|}{ Concentration (mg/mL) } \\
\hline & \multicolumn{2}{|c|}{ S. aureus } & \multicolumn{2}{|c|}{ B. subtilis } & \multicolumn{2}{|c|}{ E. coli } & \multicolumn{2}{|c|}{ K. pneumoniae } & \multicolumn{2}{|c|}{ P. aeruginosa } \\
\hline & MIC & MBC & MIC & MBC & MIC & MBC & MIC & MBC & MIC & MBC \\
\hline NsME & 1.56 & 6.25 & 1.56 & 12.5 & 6.25 & 50 & 6.25 & 12.5 & 1.56 & 25 \\
\hline NsEAE & 0.39 & 3.12 & 1.56 & 6.25 & 1.56 & 25 & 3.12 & 12.5 & 1.56 & 12.5 \\
\hline
\end{tabular}

NsME - methanolic extract obtained from rice culture medium.

NsEAE - ethyl acetate extract obtained from the filtrate of the culture in Potato Dextrose Broth (PDB) medium.

TABLE 4 | Phytochemical analysis of the extracts from N. sphaerica (URM-6060) isolated from leaves of $I$. suffruticosa.

\begin{tabular}{|c|c|c|c|c|c|c|c|c|c|}
\hline \multirow[t]{2}{*}{ Extract } & \multicolumn{9}{|c|}{ Compound } \\
\hline & Steroid & Saponin & Alkaloid & Flavonoid & Tannin & Sugar & Terpenoids & Cinnamic derivatives & Anthracene derivatives \\
\hline NsME & + & - & + & - & + & + & + & + & - \\
\hline NsEAE & + & - & + & - & + & + & + & + & + \\
\hline
\end{tabular}

NSME - methanolic extract obtained from rice culture medium.

NsEAE - ethyl acetate extract obtained from the filtrate of the culture in PDB medium.

from 3.12 to $50 \mathrm{mg} / \mathrm{mL}$, respectively. In fact the strongest activity was found against $S$. aureus (MIC of $0.39 \mathrm{mg} / \mathrm{mL}$ and MCB of $3.12 \mathrm{mg} / \mathrm{mL}$ ), followed by B. subtilis (MIC of $1.56 \mathrm{mg} / \mathrm{mL}$ and MCB of $6.25 \mathrm{mg} / \mathrm{mL}$ ) and P. aeruginosa (MIC of $1.56 \mathrm{mg} / \mathrm{mL}$ and MCB of $12.5 \mathrm{mg} / \mathrm{mL}$ ), E. coli (MIC of $1.56 \mathrm{mg} / \mathrm{mL}$ and MCB of $25 \mathrm{mg} / \mathrm{mL}$ ), and $K$. pneumoniae (MIC of $3.12 \mathrm{mg} / \mathrm{mL}$ and MCB of $12.5 \mathrm{mg} / \mathrm{mL}$ ). This extract also showed bacteriostatic actions $(\mathrm{MBC} / \mathrm{MIC} \geq 4)$.

\section{Phytochemical Screening of the NsME and NsEAE Extracts of the Endophytic Fungus N. sphaerica (URM-6060)}

Phytochemical analysis revealed the presence of terpenoids, steroids, hydrolyzable tannins, alkaloids, and cinnamic derivatives (Table 4). Both extracts showed the same chemical constitution, except for the presence of anthracene derivatives in NsEAE. All these classes of compounds have been reported as antimicrobial agents.

\section{Discussion}

One of the most important properties of endophytic microorganisms, especially fungi, is linked to their metabolic potential to produce a large variety of bioactive molecules that can protect the plant against pathogens (Tan and Zou, 2001; Strobel, 2003). For example, natural compounds synthesized by endophytic fungi have been reported as inhibitors of a wide variety of animal and plant pathogens (Wiyakrutta et al., 2004; Gunatilaka, 2006; Zhao et al., 2011b). The isolation and identification of endophytic mycobiota is necessary, since the medicinal properties of a plant can be a consequence of the capacity of its endophytic microorganisms to produce biologically active secondary metabolites (Kaul et al., 2012; Kusari et al., 2013). This was the case in the classic example of taxol, an anticancer agent produced by Taxus brevifolia Nutt., and its endophyte Taxomyces andreanae (Stierle et al., 1993).

In the present work 65 endophytic strains were isolated from the medicinal plant I. suffruticosa and the antimicrobial activity of them was evaluated. A total of $18(33.6 \%)$ strains showed antibacterial activity, most of them $(17 / 18 ; 94.44 \%)$ with wide spectrum. The percentage of endophytic fungi isolated from leaves of $I$. suffruticosa showed that antimicrobial activity was comparable and even exceeding some results reported by other authors in similar studies, revealing the enormous capacity of production of bioactive compounds with antimicrobial potential by these microorganisms. For example, only $8.3 \%$ of the strains isolated from Dracaena cambodiana and Aquilaria sinensis showed antimicrobial activity (Gong and Guo, 2009), whereas $27.6 \%$ of strains isolated from Camptotheca acuminata displayed antimicrobial activity against some pathogens (Lin et al., 2007).

The two most active strains (N. sphaerica URM-6060 and P. maculans URM-6061) were further examined using liquid and semi-solid fermentation assays. Only N. sphaerica URM6060 showed antibacterial activity (only in PDB, SAB, and rice media), and the best results were found using PDB medium. Similar results were observed by Siqueira et al. (2011) in a study of the antimicrobial activity of endophytic fungi from Lippia sidoides Cham., where 16 out of 203 endophytic isolates showed antimicrobial activity in an assay on solid medium, and of the 16 endophytic fungi which were submitted to the fermentation assay, 10 displayed antimicrobial activity. The production of a bioactive compound by an endophyte can be stimulated in the host plant or by a host plant extract. When grown in vitro, an endophyte may continue to produce bioactive material, or this may cease after a certain time. Research is needed to discover what factors could encourage endophytes to continue synthesizing compounds in vitro (Owen and Hundley, 2004). 
Endophytic fungi from the genus Nigrospora have been reported as rich sources of bioactive secondary metabolites with applications in various fields. Such secondary metabolites include herbicidal phomalactone (Kim et al., 2001), phytotoxic and antibacterial nigrosporins (Tanaka et al., 1997), phytotoxic lactones (Fukushima et al., 1998), and activity against plant pathogenic fungi (Zhao et al., 2012). In this work the best antimicrobial action was found with NsEAE, this extract was most active against $S$. aureus. This extract is composed of terpenoids, steroids, hydrolyzable tannins, alkaloids, cinnamic derivatives, and anthracene derivatives, all of them reported to be antimicrobial agents (Funatogawa et al., 2004; Yu et al., 2010; Du et al., 2012; Sova, 2012; Mousa and Raizada, 2013).

Specifically, the production of terpenoids by endophytic fungi and their biological activities were reported in a recent review (Souza et al., 2011). The steroid ergosta-7,9 (14), 22-triene-3 $\beta$ ol, produced by the endophytic fungus $N$. sphaerica isolated from leaves of Vinca rosea, showed antifungal activity against Cryptococcus neoformans with an IC50 value of $14.81 \mu \mathrm{g} / \mathrm{mL}$ (Metwaly et al., 2014). The incubation temperature, medium composition, and degree of aeration affect the amount and kinds of compounds that are produced by an endophytic fungus (Strobel et al., 2004). The culture medium, agitation, and temperature can increase or reduce the production of the bioactive compounds by fungi. For this reason, further tests are needed to evaluate the biological activity of the strains that showed inhibition on solid media but did not produce bioactive compounds during the fermentation assay. The production of a bioactive compound by an endophyte can be stimulated in the host plant or by a host plant extract. Other explanations for this may be the presence of some inhibitory compound in the extract, the range of

\section{References}

Aksoy, D. Y., and Unal, S. (2008). New antimicrobial agents for the treatment of Gram-positive bacterial infections. Clin. Microbiol. Infect. 14, 411-420. doi: 10.1111/j.1469-0691.2007.01933.x

Almeida, E. R., Chaves, T. M., Luna, R. L. A., Silva, A. R., Aragão-Neto, A. C., Silva, L. L. S., et al. (2013). Anticonvulsant effect of Indigofera suffruticosa Mill: indication of involvement of the GABAergic system. Afr. J. Pharm. Pharacol. 7, 622-628. doi: 10.5897/AJPP12.1262

Aly, A. H., Edrada-Ebel, R., Wray, V., Müller, W. E. G., Kozytska, S., Hentschel, U., et al. (2008). Bioactive metabolites from the endophytic fungus Ampelomyces sp. isolated from the medicinal plant Urospermum Picroides. Phytochemistry 69, 1716-1725. doi: 10.1016/j.phytochem.2008.02.013

Araújo, W. L., Marcon, J., Maccheroni, W. Jr., Van Elsas, J. D., Van Vuurde, J. W., and Azevedo, J. L. (2002). Diversity of endophytic bacterial populations and their interaction with Xylella fastidiosa in citrus plants. Appl. Environ. Microbiol. 68, 4906-4914. doi: 10.1128/AEM.68.10.4906-4914.2002

Bauer, A. M., Kirby, W. M. M., Sherris, J. C., and Turck, M. (1966). Antibiotic susceptibility testing by a standardized single disk method. Am. J. Clin. Pathol. 45, 493-496.

Bezerra dos Santos, A. T., Araújo, T. F. D. S., Da Silva, L. C. N., Silva, C. B. D., Oliveira, A. F. M. D., Araújo, J. M., et al. (2015). Organic extracts from Indigofera suffruticosa leaves have antimicrobial and synergic actions with Erythromycin against Staphylococcus aureus. Front. Microbiol. 6:13. doi: 10.3389/fmicb.2015.00013

Carli, C. B. A., Quilles, M. B., Maia, D. C., Lopes, F. C., Santos, R., Pavan, F. R., et al. (2010). Antimycobacterial activity of Indigofera suffruticosa with activation potential of the innate immune system. Pharm. Biol. 48, 878-882. doi: $10.3109 / 13880200903303471$ concentration of extract tested and the pathogenic fungi selected for the test (Pawle and Singh, 2014).

Furthermore, our observations indicate that endophytic fungi from leaves of $I$. suffruticosa have pharmaceutical potential as they produce antimicrobial compounds, and that the medicinal properties of this plant may be a consequence of the capacity of its endophytic microorganisms to produce biologically active secondary metabolites. Further studies are now needed to identify the active compounds produced in order to discover new drugs with antibacterial activity.

\section{Author Contributions}

Conceived and designed the experiments: IPS, VLML, and MSC. Performed the experiments: IPS and MSC. Analyzed the data: VLML, MSC, LCNA, and JMA. Contributed reagents/materials/analysis tools: VLML, MSC, and JMA. Wrote and enriched the literature: IPS, LCNA, VLML, and MVS.

\section{Acknowledgments}

The authors thank the Brazilian agencies Fundação de Amparo à Ciência e Tecnologia do Estado de Pernambuco (FACEPE), Coordenacão de Aperfeiçoamento de Pessoal de Nível Superior (CAPES), and Conselho Nacional de Desenvolvimento Científico e Tecnológico $(\mathrm{CNPq})$ for their financial support. We express our gratitude to Scott V. Heald, a native of the United States and certified English language examiner, for correcting the English of the manuscript.

Chen, T. Y., Sun, H. L., Yao, H. T., Lii, C. K., Chen, H. W., Chen, P. Y., et al. (2013). Suppressive effects of Indigofera suffruticosa Mill extracts on lipopolysaccharide-induced inflammatory responses in murine RAW 264.7 macrophages. Food Chem. Toxicol. 55, 257-264. doi: 10.1016/j.fct.2012.12.056

Costelloe, C., Metcalf, C., Lovering, A., Mant, D., and Hay, A. D. (2010). Effect of antibiotic prescribing in primary care on antimicrobial resistance in individual patients: systematic review and meta-analysis. BMJ 340:c2096. doi: 10.1136/bmj.c2096

Deshmukh, S. K., Verekar, S. A., and Bhave, S. V. (2014). Endophytic fungi: a reservoir of antibacterials. Front. Microbiol. 5:715. doi: 10.3389/fmicb.2014.00715

Du, F. Y., Li, X. M., Li, C. S., Shang, Z., and Wang, B. G. (2012). Cristatumins A-D, new indole alkaloids from the marine-derived endophytic fungus Eurotium cristatum EN-220. Bioorg. Med. Chem. Lett. 22, 4650-4653. doi: 10.1016/j.bmcl.2012.05.088

Fukushima, T., Tanaka, M., Gohbara, M., and Fujimori, T. (1998). Phytotoxicity of three lactones from Nigrospora sacchari. Phytochemistry. 48, 625-630. doi: 10.1016/S0031-9422(97)01023-6

Funatogawa, K., Hayashi, S., Shimomura, H., Yoshida, T., Hatano, T., Ito, H., et al. (2004). Antibacterial activity of hydrolyzable tannins derived from medicinal plants against Helicobacter pylori. Microbiol. Immunol. 48, 251-261. doi: 10.1111/j.1348-0421.2004.tb03521.x

Gong, L. J., and Guo, S. H. (2009). Endophytic fungi from Dracaena cambodiana and Aquilaria sinensis and their antimicrobial activity. Afr. J. Biotechnol. 8, 731-736. doi: 10.5897/AJB2009.000-9124

Gunatilaka, A. A. L. (2006). Natural products from plant-associated microorganisms: distribution, structural diversity, bioactivity and applications of their occurrence. J. Nat. Prod. 69, 509-526. doi: 10.1021/np058128n

Harborne, J. B. (1998). Phytochemical Methods. London: Chapman \& Hall, 60-66. 
Ichikawa, T., Date, M., Ishikura, T., and Ozaki, A. (1971). Improvement of kasugamycin-producing strain by the agar piece method and the prototroph method. Folia Microbiol. 16, 218-224. doi: 10.1007/BF02884210

Kaul, S., Gupta, S., Ahmed, M., and Dhar, M. K. (2012). Endophytic fungi from medicinal plants: a treasure hunt for bioactive metabolites. Phytochem. Rev. 11, 487-505. doi: 10.1007/s11101-012-9260-6

Kim, J. C., Choi, G. J., Park, J. H., Kim, H. T., and Cho, K. Y. (2001). Activity against plant pathogenic fungi of phomalactone isolated from Nigrospora sphaerica. Pest Manag. Sci. 57, 554-559. doi: 10.1002/ps.318

Kokate, C. K. (1994). Practical Pharmacognosy. New Delhi: Vallabh Prakashan, $107-113$.

Kusari, S., Pandey, S. P., and Spiteller, M. (2013). Untapped mutualistic paradigms linking host plant and endophytic fungal production of similar bioactive secondary metabolites. Phytochemistry 91, 81-87. doi: 10.1016/j.phytochem.2012.07.021

Leite, S. P., Medeiros, P. L., Silva, E. C., Maia, M. B. S., Lima, V. L. M., and Saul, D. E. (2004). Embryotoxicity in vitro with extract of Indigofera suffruticosa leaves. Reprod. Toxicol. 18, 701-705. doi: 10.1016/j.reprotox.2004.04.004

Leite, S. P., Vieira, J. R. C., Madeiros, P. L., Leite, R. M. P., Lima, V. L. M., Xavier, H. S., et al. (2006). Antimicrobial activity of Indigofera suffruticosa. Evid. Based Complement. Alternat. Med. 3, 261-265. doi: 10.1093/ecam/nel010

Li, H. Y., Wei, D. Q., Shen, M., and Zhou, J. P. (2012). Endophytes and their role in phytoremediation. Fungal Divers. 54, 11-18. doi: 10.1007/s13225-012-0165-x

Lin, X., Lu, C., Huang, Y., Zheng, Z., Su, W., and Shen, Y. (2007). Endophytic fungi from a pharmaceutical plant, Camptotheca acuminata: isolation, identification and bioactivity. World J. Microbiol. Biotechnol. 23, 1037-1040. doi: 10.1007/s11274-006-9329-8

Luiz-Ferreira, A., Cola, M., Barbastefano, V., Farias-Silva, E., Calvo, T. R., Almeida, A. B. A., et al. (2011). Indigofera suffruticosa Mill as new source of healing agent: involvement of prostaglandin and mucus and heat shock proteins. J. Ethnopharmacol. 137, 192-198. doi: 10.1016/j.jep.2011.05.006

Mapperson, R. R., Kotiw, M., Davis, R. A., and Dearnaley, J. D. W. (2014). The diversity and antimicrobial activity of Preussia sp. endophytes isolated from australian dry rainforests. Curr. Microbiol. 68, 30-37. doi: 10.1007/s00284-0130415-5

Metwaly, A. M., Kadry, H. A., El-Hela, A. A., Mohammad, A. E. I., Ma, G., Cutler, S. J., et al. (2014). Nigrosphaerin A a new isochromene derivative from the endophytic fungus Nigrospora sphaerica. Phytochem. Lett. 7, 1-5. doi: 10.1016/j.phytol.2013.09.001

Mousa, W. K., and Raizada, M. N. (2013). The diversity of anti-microbial secondary metabolites produced by fungal endophytes: an interdisciplinary perspective. Front. Microbiol. 4:65. doi: 10.3389/fmicb.2013.00065

National Committee for Clinical Laboratory Standards [NCCLS]. (2009). Reference Method for Broth Dilution Antifungal Susceptibility Testing of Yeasts, Approved Standard-Second Edition M27-A2. Wayne, PA: National Committee for Clinical Laboratory Standards.

Owen, N. L., and Hundley, N. (2004). Endophytes - the chemical synthesizers inside plants. Sci. Prog. 87, 79-99. doi: 10.3184/003685004783238553

Pankey, G. A., and Sabath, L. D. (2004). Clinical relevance of bacteriostatic versus bactericidal mechanisms of action in the treatment of Gram-positive bacterial infections. Clin. Infect. Dis. 38, 864-870. doi: 10.1086/381972

Pawle, G., and Singh, S. K. (2014). Antimicrobial, antioxidant activity and phytochemical analysis of an endophytic species of Nigrospora isolated from living fossil Ginkgo biloba. Curr. Res. Environ. Appl. Mycol. 4, 1-9. doi: $10.5943 / \mathrm{cream} / 4 / 1 / 1$

Porras-Alfaro, A., and Bayman, P. (2011). Hidden fungi, emergent properties: endophytes and microbiomes. Annu. Rev. Phytopathol. 49, 291-315. doi: 10.1146/annurev-phyto-080508-081831

Radić, N., and Štrukelj, B. (2012). Endophytic fungi - the treasure chest of antibacterial substances. Phytomedicine 19, 1270-1284. doi: 10.1016/j.phymed.2012.09.007

Rodriguez, R. J., White, J. F. Jr., Arnold, A. E., and Redman, R. S. (2009). Fungal endophytes: diversity and functional roles. New Phytol. 182, 314-330. doi: 10.1111/j.1469-8137.2009.02773.x

Siqueira, V. M., Conti, R., Araújo, J. M., and Souza-Motta, C. M. (2011). Endophytic fungi from the medicinal plant Lippia sidoides Cham. and their antimicrobial activity. Symbiosis 53, 89-95. doi: 10.1007/s13199-011-0113-7
Souza, J. J., Vieira, I. J. C., Rodrigues-Filho, E., and Braz-Filho, R. (2011). Terpenoids from endophytic fungi. Molecules 16, 10604-10618. doi: $10.3390 /$ molecules 161210604

Sova, M. (2012). Antioxidant and antimicrobial activities of cinnamic acid derivatives. Mini Rev. Med. Chem. 12, 749-767. doi: 10.2174/1389557128012 64792

Stierle, A., Strobel, G. A., and Stierle, D. (1993). Taxol and taxene production by Taxomyces andreanae an endophytic fungus of pacific yew. Science 260, 214-216. doi: 10.1126/science.8097061

Strobel, G. A. (2003). Endophytes as sources of bioactive products. Microbes Infect. 5, 535-544. doi: 10.1016/S1286-4579(03)00073-x

Strobel, G., Daisy, B., Castillo, U., and Harper, J. (2004). Natural products from endophytic microorganisms. J. Nat. Prod. 67, 257-268. doi: 10.1021/np030397v

Tan, R. X., and Zou, W. X. (2001). Endophytes: a rich source of functional metabolites. Nat. Prod. Rep. 18, 448-459. doi: 10.1039/b 1009180

Tanaka, M., Fukushima, T., Tsujiro, Y., and Fujimori, T. (1997). Nigrosporins $\mathrm{A}$ and $\mathrm{B}$, new phytotoxic and antibacterial metabolites produced by a fungus Nigrospora oryzae. Biosci. Biothecnol. Biochem. 61, 1848-1852. doi: 10.1271/bbb.61.1848

Teiten, M. H., Mack, F., Debbab, A., Aly, A. H., Dicato, M., Proksch, P., et al. (2013). Anticancer effect of altersolanol A, a metabolite produced by the endophytic fungus Stemphylium globuliferum, mediated by its pro-apoptotic and anti-invasive potential via the inhibition of NF-kB activity. Bioorg. Med. Chem. 21, 3850-3858. doi: 10.1016/j.bmc.2013.04.024

Trisuwan, K., Rukachaisirikul, V., Sukpondma, Y., Preedanon, S., Phongpaichit, S., Rungjindamai, N., et al. (2008). Epoxydons and a pyrone from the marinederived fungus Nigrospora sp. PSU-F5. J. Nat. Prod. 71, 1323-1326. doi: $10.1021 / \mathrm{np} 8002595$

von Nussbaum, F., Brands, M., Hinzen, B., Weigand, S., and Häbich, D. (2006). Antibacterial natural products in medicinal chemistry-exodus or revival? Angew. Chem. 45, 5072-5129. doi: 10.1002/anie.200600350

Wiyakrutta, S., Sriubolmas, N., Panphut, W., Thongon, N., Danwisetkanjana, K., Ruangrungsi, N., et al. (2004). Endophytic fungi with anti-microbial, anti-cancer and anti-malarial activities isolated from Thai medicinal plants. World J. Microbiol. Biotechnol. 20, 265-272. doi: 10.1023/B:WIBI.0000023832. 27679.a8

Xing, Y. M., Chen, J., Cui, J. L., Chen, X. M., and Guo, S. X. (2011). Antimicrobial activity and biodiversity of endophytic fungi in Dendrobium devonianum and Dendrobium thyrsiflorum from Vietman. Curr. Microbiol. 62, 1218-1224. doi: 10.1007/s00284-010-9848-2

Yu, H., Zhang, L., Li, L., Zheng, C., Guo, L., Li, W., et al. (2010). Recent developments and future prospects of antimicrobial metabolites produced by endophytes. Microbiol. Res. 165, 437-449. doi: 10.1016/j.micres.2009.11.009

Zhao, J., Shan, T., Mou, Y., and Zhou, L. (2011a). Plant-derived bioactive compounds produced by endophytic fungi. Mini Rev. Med. Chem. 11, 159-168. doi: 10.2174/138955711794519492

Zhao, K., Penttinen, P., Guan, T., Xiao, J., Chen, Q., Xu, J., et al. (2011b). The diversity and anti-microbial activity of endophytic actinomycetes isolated from medicinal plants in Panxi Plateau, China. Curr. Microbiol. 62, 182-190. doi: 10.1007/s00284-010-9685-3

Zhao, J. H., Zhang, Y. L., Wang, L. W., Wang, J. Y., and Zhang, C. L. (2012). Bioactive secondary metabolites from Nigrospora sp. LLGLM003, an endophytic fungus of the medicinal plant Moringa oleifera Lam. World J. Microbiol. Biotechnol. 28, 2107-2112. doi: 10.1007/s11274-0121015-4

Conflict of Interest Statement: The authors declare that the research was conducted in the absence of any commercial or financial relationships that could be construed as a potential conflict of interest.

Copyright (c) 2015 Santos, Silva, Silva, Araújo, Cavalcanti and Lima. This is an open-access article distributed under the terms of the Creative Commons Attribution License (CC BY). The use, distribution or reproduction in other forums is permitted, provided the original author(s) or licensor are credited and that the original publication in this journal is cited, in accordance with accepted academic practice. No use, distribution or reproduction is permitted which does not comply with these terms. 